\title{
BESTIA TRIUMPHANS: ENRIQUE STANKO VRÁZ IN BEIJING IN 1901
}

\author{
Iveta Nakládalová ${ }^{1}$
}

\begin{abstract}
This study focuses on a description of the Boxer Rebellion in Beijing, in the first months of 1901, written by E. S. Vráz during his second journey to China. Enrique Stanko Vráz (1860-1932) was a Czech naturalist and explorer, renowned for his travels to Africa, Latin America, and Asia, which he depicted in a series of books addressed to a broader public.

His travelogue on Beijing during the Boxer Rebellion is particularly engaging, since it shows the country in the midst of great turmoil and chaos, just after the uprising had reached its climax. It is also extremely interesting from the ethnographical and anthropological perspective, because Vráz not only comments on the activities of the allied forces in China, but he also describes the Chinese people, their customs, Chinese culture and society, and in doing so develops an interpretation of the kingdom, governed by the dichotomy between 'civilization' and modernity, on one hand, and 'barbarism' and obscurantism, on the other.

Vráz's narrative therefore seems to be inexorably bound to an ethnocentric paradigm, so characteristic of travel writing at the beginning of the $20^{\text {th }}$ century. I argue, however, that this statement is oversimplifying, and that Vráz's text is self-aware of these antagonisms and therefore defies any straightforward reading.
\end{abstract}

KEYWORDS: travel literature - Enrique Stanko Vráz - China - Boxer Rebellion - travel photography

\section{Introduction}

In my texts I try to be impartial. Although I myself am white, and I am proud of the achievements and virtues of my race, I have lived enough - more than 15 years - with differently-coloured, differently-thinking people, and have rid myself of many prejudices. ${ }^{2}$

Enrique Stanko Vráz (born 1860) was a Czech traveller and writer. Of dubious origin (he might have been born in Bulgarian Tarnovo, even though his first years of life are hidden in mystery, to which Vráz only adds by using several names, passports, and identities), he wrote his books and travelogues in Czech. He is known for his intrepid life, full of adventures and activity as a traveller, explorer (one of his journeys to Latin

1 Contact: Iveta Nakládalová, Palacký University Olomouc, Czech Republic; e-mail: ivetanak@gmail. com. The research for this article has received support from the European Regional Development Fund Project 'Sinophone Borderlands - Interaction at the Edges', CZ.02.1.01/0.0/0.0/16_019/0000791.

2 Vráz 1904, p. 3. 


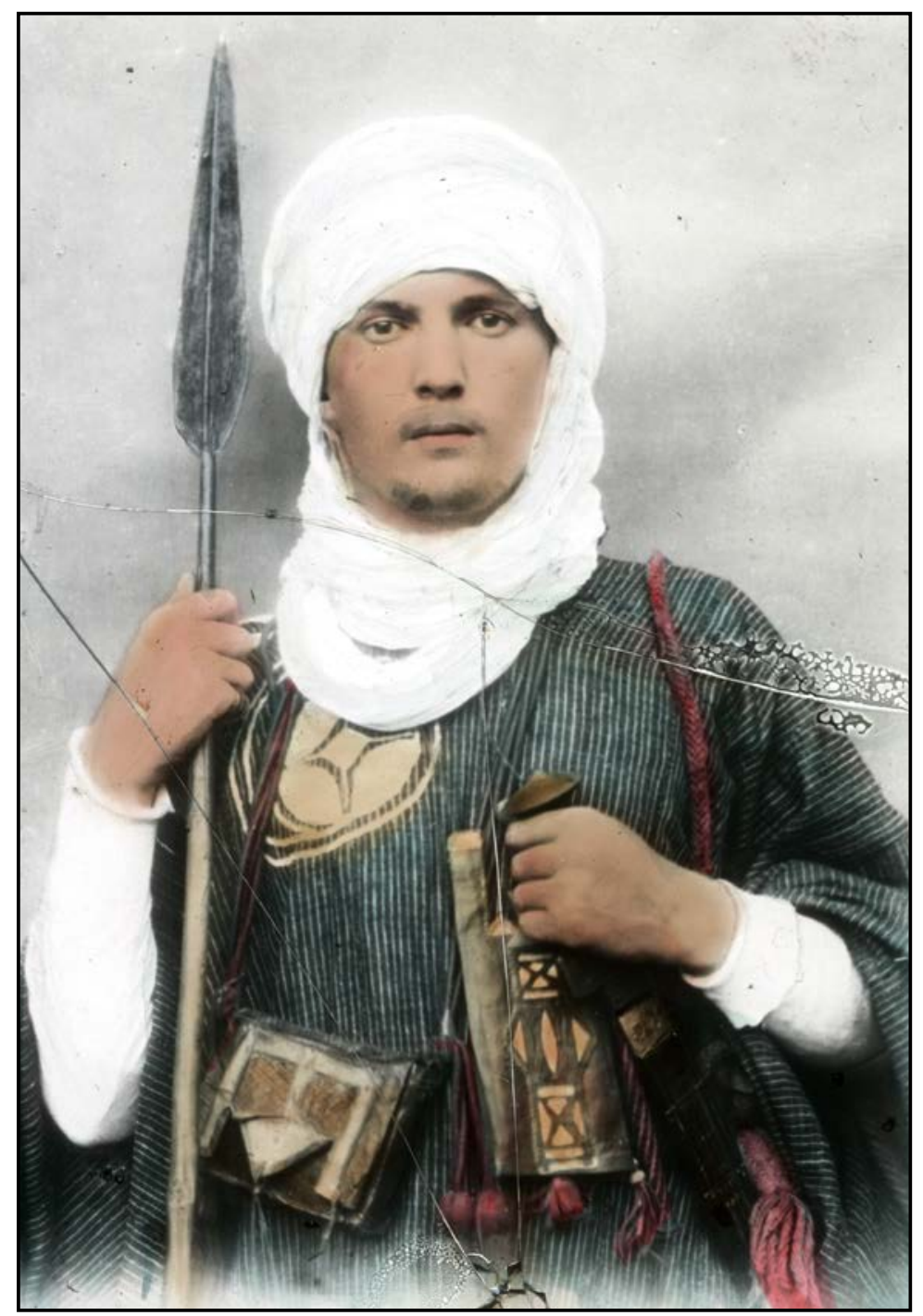

Fig. 1. Portrait of young Enrique Stanko Vráz in the attire of the Hausa people, Ghana, 1885-1888. Náprstek Museum, Inv. no. Af II 2105.

America was inspired by the expeditions of the great German scientist Alexander von Humboldt), entrepreneur, writer, lecturer, and photographer. He collected ethnographic material, together with botanical and animal specimens on his journeys, ${ }^{3}$ and devoted himself to photography on glass plates, an extremely laborious and arduous technology (especially in the challenging conditions of a subtropical and tropical climate). He

3 Vráz's personal documents, correspondence, his personal archive and, particularly, his photo archive (which includes several thousand slides and negatives) are kept in the Náprstek Museum (Náprstek Museum of Asian, African and American Cultures) in Prague. See Todorovová 2006, p. 3. 
is not an unfamiliar author in Czech scholarship (several studies on him have actually been published in this very journal). He remains, however, quite an enigmatic figure and his texts are still, to a great extent, in need of deeper exploration. This is not only due to the fact that their undeniable literary qualities remain unacknowledged (as well as revealing his extraordinary personality and fascinating life), but also because they resist the oversimplified perception that labels Vráz as a typical example of the ethnographic narrative at the turn of the $20^{\text {th }}$ century, which is immersed in the ethnocentric paradigm and which resorts to a set of well-known interpretative oppositions (led by the dominant antagonism between 'barbarism' and 'civilization'). For the reviewer, for example, of an abridged version of his Napřič rovnikovou Amerikou (Across Equatorial America), published in 1984, Vráz's view of the native Indians, 'despite his sympathy for them', is that of a member of civilized society who is looking at 'savages' ${ }^{4}$ As the matter of fact, in the travelogue studied in the present article, Vráz describes and interprets China and its society and culture, and does so in a set of antitheses, characteristic for the poetics of the 'exotic' travel narrative of his time ('modernity, civilization, novelty and progress' set against 'barbarism, obscurantism, reactionary spirit, and superstition') and for Vráz's own scientific and positivist spirit.

Nevertheless - and this is one of the main objectives of the present study - I would argue that he is also an example of a traveller who did not remain untouched and untransformed by what he saw and what he experienced, and this makes him especially interesting for a contemporary readership. To ascribe his texts, without further scrutiny, to the ethnocentric paradigm would be oversimplifying. The fact that Vráz is acutely aware of these antagonisms, together with his attempt to 'explain China' from its own cultural and social categories and in the context of the kingdom's historical development, turns his account into a text that defies any straightforward reading, and should be examined from an ethnographic as well as literary and symbolic perspective.

Vráz's first journey out of Europe led him, in 1880, to North and later into inner Africa, where he would begin to practice photography. He then spent some time on the Canary Islands, from where he went back to Africa. He returned for a short stay to the Canary Islands before sailing to Venezuela (in 1889), where he began to work as a merchant and even obtained citizenship. Once he accumulated enough money, he set off (in 1892) for a major journey to navigate the huge rivers of South America (the Orinoco, the Amazonas). He returned to Prague and gave a series of lectures on his travels, with great success, even within the circle of Vojtěch Náprstek, the celebrated Czech philanthropist, collector, and the founder of the well-known museum in Prague. He set off for Japan in 1895, stopping in North America. From Japan, he travelled to Singapore, Borneo, and New Guinea, back to Singapore and to Siam (today's Thailand), and probably also, on this first occasion, to China. ${ }^{5}$

In 1901, after the Boxer Rebellion broke out, he travelled again to Beijing, where - using his American passport - he was allowed to enter the Forbidden City, took hundreds of photographs and kept meticulous travel diaries. He moved, through Korea and Siberia, back to Europe, and over the years 1903-1904 returned to South and Central

4 Stiborová 1985, p. 114.

5 This visit to China is not mentioned in Todorovová 2006. However, in the report on his 1901 visit to Beijing, Vráz refers more than once to this first journey to Beijing, Nanjing, and Shanghai, five years prior to the second trip in 1901. See Vráz 1904, and note 27 below. 
America. He then lived with his family (he married Vlasta Gering - an American with Czech roots - in 1897) between Chicago and Prague. He died in 1932, after a long period of serious health issues, including malaria, which he undoubtedly brought upon himself by his travel endeavours. ${ }^{6}$

Vráz authored several books, mainly descriptions of his journeys, including volumes on his visits to Asia (namely: China. Travel Vignettes; White Devil in Beijing. Travels and Adventures in China; In the Land of the White Elephant. Travels and Adventures in Siam; The Seventh Sea. New Guinea, Borneo and Japan). This study focuses on the report on his second journey to China (to Beijing) in 1901, published as the third volume of the World Travels series, in 1904, under the title China. Travel Vignettes.

\section{Travels Accounts of China at the Turn of the $20^{\text {th }}$ Century}

The report undoubtedly reflects the European accounts of China at the end of the $19^{\text {th }}$ and the beginning of the $20^{\text {th }}$ century. As a matter of fact, all Vráz's travelogues should be examined in the context of the genre of 'travel narrative' which has become, in the last decades, object of innumerable studies, despite the neglect of former scholarship, which regarded it as 'subliterary'. This increase in scholarly attention was motivated, in the first place, by the awareness that the travel writing is, actually, one of the birth-places of modern ethnography and cultural anthropology. In the second place, it is also bound to the emergence and consolidation of postcolonial theory, postcolonial imagology and imperial history. This is particularly true for the so-called 'colonial' or 'imperial' travelogues, that is, travel accounts produced by the members of the 'Empires' who travelled to the colonized (or to-be-colonized) territories during the 'long $19^{\text {th }}$ century'. As far as Asia is concerned, many studies were produced by the Anglo-Saxon and French scholarship reflecting on the travels into the territories of their previous imperial interest. ${ }^{7}$

That is also the case of the travelogues on China at the turn of the $20^{\text {th }}$ century. A relatively recent collection of essays on the topic (A Century of Travels in China. Critical Essays on Travel Writing from the 1840s to the 1940s) deals exclusively with the British and the Americans. The same approach can be observed in Thurin's Victorian Travelers and the Opening of China, 1842-1907, as well as in Asian Crossings, a collection of essays on travel writing on China, Japan, and South-East Asia. From this point of view, the present article aims at contributing to the existing

6 This basic life and travel account is based on the study of Todorovová 2006, pp. 1-20. Some of the biographical data can be reconstructed from his diaries, published in a series called 'Cestopisné črty' (Travel Vignettes) by the Prague publisher Bursík a Kohout in the first years of the $20^{\text {th }}$ century. His life and travels have been outlined in a book by his daughter Vlasta Vrázová (1937). Many facts are uncertain, however, and should be taken with caution.

7 Recently, there has been an extremely fruitful tendency to complement the study of the travel narrative produced in the 'centre' (that is, within the geographical and cultural context of great imperial powers) with views from the 'periphery', for example, from Eastern and Central Europe. See, e.g. Ewertowski 2020. It is also the case of the workshop Escaping Kakania: Eastern European Travels in Colonial Southeast Asia, hosted by the National University of Singapore in March 2021. As the result of the encounter, a collective volume focused on these long-neglected travelogues from the AustroHungarian Empire is to be published. In the context of travel accounts of China in the first half of the $20^{\text {th }}$ century, the works of Ferdynand Antoni Ossendowski, a well-known Polish explorer who wrote several books on the country, are of particular interest. 
scholarship, focusing on a traveller who has never been the object of analysis outside the strictly national context. ${ }^{8}$

Methodologically speaking, as I have already anticipated, the exploration of the late $19^{\text {th }}$ and early $20^{\text {th }}$ century travel writing has benefitted most from the postcolonial theory. Unsurprisingly, the framework of postcolonial studies is somehow inherent to travel literature, especially in the colonial period, because one of the purposes (albeit often unconscious) of the journey to the 'periphery' is to constitute and legitimize the 'centre':

Travel writing not only had volume, popularity and reach during the colonial era, due to its capacity to generate curiosity, excitement, and adventure, it was also instrumental in the economy and machinery of Empire: if the imperial centre depended on representations of its peripheries and others to know itself, and to provide a sense of ownership, entitlement, and legitimacy, travel writing served up plenty of material for that purpose $[\ldots] .^{9}$

The canonic assessment of travel narrative carried out by postcolonial scholarship is probably best exemplified in the works of David Spurr (The Rhetoric of Empire: Colonial Discourse in Journalism, Travel Writing and Imperial Administration, 1993), Ali Behdad (Belated Travellers: Orientalism in the Age of Colonial Dissolution, 1994), and Mary Louise Pratt (Imperial Eyes: Travel Writing and Transculturation, 1992), because they all employ the Foucauldian discourse analysis in order to reveal how the construction of the colonialized 'Other' is embedded into the very fabric of the narration, and how the travellers use their own European categories in the interpretation of this Other. Furthermore, they all ponder, in one way or another, on the impact of Said's seminal Orientalism (and on that of his followers). And although they assess it sometimes from a rather critical perspective, they do ponder upon the central notions of postcolonial studies: the interpretation and construction of the Other, the stereotipization and exoticization, the use of the discourse of 'Otherness' in order to preserve the imperial power and authority, and the role of the travel narrative in constructing the identity of the Self through the Other.

\section{Vráz's Account of 1901 Beijing}

Many these aspects play an important role also in Vráz's description of Beijing just in the aftermath of the Boxer rebellion. It is a particularly engaging account, because it does not depict his first contact with the country but rather, from the symbolic perspective,

8 See, furthermore, Fritzsche 1995. Unfortunately, I was not able to access the full contents of this Ph.D. thesis. Cf. Clifford 2001, and Dawson 1967. For a non-Anglo-Saxon perspective, see for example: Qing 2014. For French scholarship, see Berty 2001, and Wetzel 1992. Of particular attention for this paper are travelogues written by soldiers, which have received so far only very limited scholarly attention. See, for example, the report of Theodor Ritter von Winterhalder, an Austrian soldier and later admiral who served as commander on the cruiser 'Zenta' and participated in the intervention in the Boxer Rebellion on behalf of the imperial powers. In 1902 he published an account of his experience, entitled Kämpfe in China. Eine Darstellung der Wirren und der Betheiligung von Österreich-Ungarns Seemacht an ihrer Niederwerfung in den Jahren 1900-1901 (Conflict in China. A Representation of the Turmoil and the Role of Austria-Hungary's Sea Power in the Defeat. 1900-1901).

9 Lindsay, 'Travel Writing and Postcolonial Studies', in Thompson 2016, p. 30. 
a 'journey of return': his desire is to re-encounter the 'traditional' China he got to know during his first trip. Moreover, on this second occasion in January 1901, he arrives in the midst of great turmoil and chaos, just after the Boxer Rebellion ${ }^{10}$ had reached its climax. This was a truly unexpected and inconceivable moment, as he saw China humiliated and defeated, an occasion when the imperial power was staggering. He found scenes of destruction, brought upon the country by both the Boxers and the Western nations [Figs. 2, 11]:11

The devastation in the European settlement, in the Chinese city (of Beijing), the devastation brought upon [the country] by the Boxers together with the government's army and the allied forces, is terrible and much bigger than I assumed. Ruins and scenes of a fire everywhere. Whole neighbourhoods have been [...] burnt to ashes. ${ }^{12}$

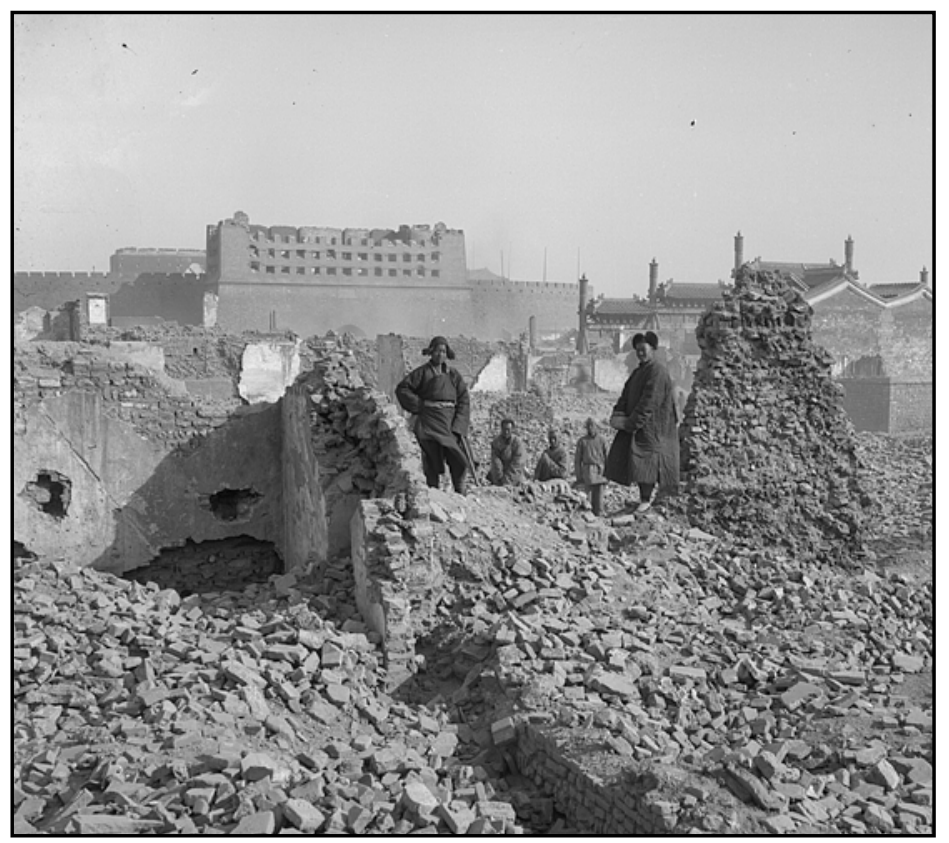

Fig. 2. Ruins of Beijing. Náprstek Museum, Inv. no. As I 7178.

10 The Boxer Rebellion (or the Boxer Rising) was an anti-imperialist, anti-foreign, and anti-Christian uprising in China between 1899 and 1901 (at the end of the Qing Dynasty). Vráz, in his report, refers specifically to the siege of the foreigners and Chinese Christians, who sought refuge in the Beijing Legation Quarter. In their efforts to lift the siege (but also motivated undoubtedly by imperialistic and commercial interests), the Eight Nation Alliance of American, Austro-Hungarian, British, French, German, Italian, Japanese, and Russian troops invaded and looted Beijing. Many thousands of Chinese Christians and around 250 foreigners, mainly missionaries, were killed. See, for example, Fairbank 2006, pp. 230-232.

11 For a better contextualization of Vráz's assessment of the Boxer Rebellion, see Lucas 1990; cf. French 2009, and Heroldová and Todorovová 2018. Moreover, the Boxer Rebellion was also depicted in early $20^{\text {th }}$ century fiction, e.g., in Elisabeth von Heyking's novel Tschun (1914).

12 Vráz 1904, p. 77. All the translations of Vráz's texts are mine, his works have not been so far translated into English. 
Despite this reality, China still conserves some of its past charm, at least for Vráz, who describes the unexpected unveiling of previously concealed treasures, having arrived at a time in which 'all the palaces of the enchanted princess have been opened, when the guarding dragons and lions have been either taken away as war spoils, or muzzled.'13

Vráz is an intelligent and witty writer, and an attentive observer of the local customs and daily life of the city. He makes a number of comments on the mentality of the Chinese and the differences in habits between the locals and Westerners. He complements his own first-hand experience with long passages from connoisseurs of China and scholars on 'things Chinese', ${ }^{14}$ and emphasizes, on many occasions, the trustworthiness of his sources.

He does not elaborate, however, his text in a reportage-like manner, but rather as a diary, as a reflexive and personal account. It should not therefore be considered a mere travelogue: not only because it is complemented by his photographs (fascinating testimonies of China in the first year of the new century) ${ }_{1}^{15}$ but also because Vráz always tries to comprehend and explicate the complex and often puzzling aspects of Chinese society and culture. Although he is acutely aware of the fact that a traveller can only glimpse into the country's 'real essence', ${ }^{16}$ he does try to provide an 'unbiased' account in the sense that he exhibits an 'anthropological' willingness to avoid value judgments and transcend his own mental categories in order to understand the Other. This is the case when, for example, he explains the cruelty of the collective punishment as rooted in traditional Chinese thought and in the deepest social convictions (namely, in the responsibility of the whole for the crimes of an individual).${ }^{17}$

13 Vráz 1904, p. 86.

14 He quotes long passages from Arthur H. Smith's Chinese Characteristics (1894), the most widely read American work on China at the end of the $19^{\text {th }}$ and the beginning of the $20^{\text {th }}$ century, written by an acclaimed sinologist; from China in Convulsion (1901), by the same author; from Samuel Wells Williams's The Middle Kingdom. A Survey of the Geography, Government, Education, Social Life, Arts, Religion, E of the Chinese Empire and Its Inhabitants (1848), and from Robert Coltman's The Yellow Crime. Beleaguered in Pekin. The Boxer's War against the Foreigner (1901), an eyewitness account of the siege by a survivor, an American doctor resident in China.

15 I include in the present study a selection of Vráz's photographs taken during his travel to China, but only as a sort of visual illustration of the text, without any deeper analysis. There is an important number of studies of early $20^{\text {th }}$ century photographic depiction of China. Once more, they tend to focus on British, American (and French) photographers (very often important figures of early photography), and are conceived of, normally, as case studies. See, for example: China. The Land and its People. Early Photographs by John Thomson (the Scottish John Thomson travelled to Asia on several occasion, and his Illustrations of China and Its People - started in 1868 - is considered as the first photographic social document to be ever produced). See also Wright 2009. See, furthermore: Photographs of Imperial China. 1850-1912; Old Photographs of Chinese Cities. For the 'subgenre' of photographs taken by diplomats, see L'oeil du Consul. Auguste François en Chine (1896-1904), and the collection of Mumm von Schwarzenstein, German ambassador in Beijing in 1900. See the chapter 'Alfons Freiherr Mumm von Schwarzenstein - a German Envoy in 1901 China', in Thiriez 1998. For an overall assessment of the topic of the Western photography of China in the given period, see Gu 2013. Particularly important, for the present article, is Lucas 1990, because it deals with the travelogue and the photographs of James Ricalton who, like Vráz, depicts China in the midst of the Boxer Rebellion. For an introduction to Vráz's photography, see Todorovová 2016b. See also Heroldová and Todorovová 2018. 
This anthropological (or proto-anthropological, if we conceive of modern anthropology as inexorably related to cultural relativism) attitude is also manifested in the fact that he often tries to enhance insight into Chinese reality by translating it into his readers' cultural and mental categories. Thus he attempts to convey the symbolic connotations of the dragon in Chinese culture by pointing out its difference from the cultural meaning in the Czech Lands. ${ }^{18}$ In the same vein, he is aware of the possible shift in the understanding of certain cultural phenomena (a shift apprehended by modern scholarship within the notion of 'transcultural translation'). 'Like so many things in China', he explains,

parental love also differs from its conception in other nations. This term, in fact, does not elucidate the exact meaning. Translators from Chinese could certainly speak about the difficulties caused by the intricate notions of the Chinese mind and the images associated to them, expressed in Chinese by one single word. During translation, other languages must, in contrast, resort to many words, in order to express all the [existing] relations. One of these hard nuts to crack is the word ' $\mathrm{i}^{\prime}$ [禮], simply translated as 'ceremony', whereas in the Chinese mind it evokes, apart from the image of a ritual practice, also that of parental love. ${ }^{19}$

\section{Vráz's Interpretation of China}

The same ability to interpret, to describe and to provide as much insight as possible can be seen from his remark that, in reality, the 'bad image' of China in Europe is nothing but a 'representation' - analogous, to a certain extent, to the notion of cultural representation as 'shared meaning', as it has been developed within cultural studies (that is, the meaning constructed collectively, culturally, and discursively). ${ }^{20}$ The 'image of China', in Vráz's opinion, has been shaped by European misapprehension and cultural degradation: he speaks about the 'aversion to everything Chinese, which has been cultivated in our lands by mocking operettas and drawings'. This is why, 'in general due to completely wrong reasons [...], everything that comes from China is viewed with hostility; truly, everybody forces himself into searching for signs of grotesque bad taste, revealed by the distorting glasses of his own bias [...].' ${ }^{21}$

After what has been said, we might become extremely perplexed by the harshness of Vráz's criticism of Chinese superstition; he condemns especially its 'perversion' of classical Chinese thought:

From what has been explained, it is clear now that there is a considerable difference between the Confucius' original teaching, on the one hand, and the doctrine that his modern followers call by his name, on the other. It would not be an exaggeration if I compared - to make my point - the orthodoxy of contemporary Confucianists to that of a religious bigot, who uses the charitable gifts of the

18 'Dragon is, for the Chinese, something different than in our fairy-tales. He represents a good fairy, a protective deity, an icon, and image of power. To glimpse the emperor is translated into courtly language as 'to contemplate the face of the dragon'. The body of the emperor is the dragon's body, the throne is the dragon's seat, etc.'. Vráz 1904, p. 253.

Vráz 1904, p. 197.

20 See Hall 1997.

Vráz 1904, p. 265. 
pious believers to make candle offerings to every saint, lighting one of them just to be on the safe side - also for Satan. ${ }^{22}$

In a similar vein, he expresses a strong aversion for Chinese idolatry:

At the end of my visit to one of the Beijing temples, I was shown groups of 'deities' of such a hideous appearance that my eyes were filled with repugnance. I will not describe them in detail; I will only declare that no decent man - be he American or European - would ever bring his wife and children to show them these appalling monsters, and certainly he himself would not ask to see again such horrendous creations of the bad taste of Chinese idol worshippers. ${ }^{23}$

It is clear that these statements should be related to $19^{\text {th }}$ century ethnocentrism and the prevailing paradigms in the disciplines of ethnography and anthropology (and, by extension, also in the travel narrative). It is also important to remember that Vráz remains, at all times, a scientist at his very core. As a matter of fact, he designates himself explicitly as an ethnographer (in Seoul, he claims, 'I devoted myself to the study of the country and of its nation'), ${ }^{24}$ and it should be of no surprise that his standpoints are often distinctively positivist and indebted to the rationalistic $19^{\text {th }}$ century Zeitgeist with its 'progressive narrative', in the sense that they embody a deep belief in the advancement of knowledge and humanity, fuelled by science and reason and opposed to obscurantism and false creeds. ${ }^{25}$ In my opinion, there is, however, one more element we should take into account. I have argued that Vráz, in his explanation of China, tries to remain unbiased, and this implies giving voice to both sides of the story. In other words, in trying to mirror and apprehend a complex and ambiguous reality, he has to resort to contrasting concepts and, very often, to the device of paradox. For one thing, only an antithesis can provide a full account of the inherent paradoxical nature of the Middle Kingdom in itself. For Vráz, the Forbidden City (and with it, one can add, the entire country) is constantly 'oscillating between fairy tale and dust', ${ }^{26}$ and this is a telling image not only of an empire exhausted by long-term stagnation, but also of a country

22 Vráz 1904, p. 213.

23 Vráz 1904, p. 293.

24 Vráz 1904, p. 393.

25 I use the term 'Zeitgeist' loosely, in the sense of a 'paradigm' which determines and conditions the contemporary thought. For a general analysis of how the scientific narrative (namely, the notion of 'exploration') shaped the travel literature in the $19^{\text {th }}$ century, see Weber 2006. Unsurprisingly, Vráz is not the only one to raise concerns about the Chinese superstition. It was described in similar terms by many others, among them by Karl Gützlaff (1803-1851), a German Protestant missionary. See Gützlaff 1838, cap. XV: Religion; and Gützlaff 1840, p. 25. Due to the lack of space, I cannot dwell on this issue extensively. It is worth noting, however, that whereas in Vráz (as in many of his fellow travellers to China), the criticism of superstition is fuelled, in the first place, by their scientific perspective, in the case of the missionaries it tends to be related to religious notions that can be traced back to the Early Modern theological discourse on idolatry and superstitio.

Vráz 1904, p. 322. 
torn between an enduring secretiveness and closeness, ${ }^{27}$ on the one hand, and a forced intrusion brought along by the foreigners and by the Boxer Rebellion, on the other: 'Starting already in the period of 1839-1842, in the so-called 'opium war', China has constantly been a target of raids and humiliation by the whites. ${ }^{28}$

China in itself is a living paradox, cemented as it is, according to Vráz's enlightened mind, in 'Medieval' (that is, primitive and archaic) superstition [Fig. 3], ${ }^{29}$ and this also conditions his own relationship to China, articulated between love and hatred, as expressed in the following statement that is very far away from any modern (and any politically correct, for that matter) understanding of the Other:

I love China. I admire classical China, a colossus in every aspect. I honour in the Chinese people the outstanding virtues of men cultivated by a thousand-year culture that has germinated out of the thought of great scholars. I hate China. The slaves chained to the outdated remnants, the perverted disciples of the great masters, people to whom the most valuable rules of the moralists are nothing but an empty cliché. The completely selfish, cruel, idiotic, silliest superstition, thoroughly degenerated, who could love it? ${ }^{30}$

This brings us to another thematic thread that runs through Vráz's entire narrative: the opposition between barbarism, on the one hand, and civilization, on the other. As we might infer from what has been already said, this 'barbaric nature' is one of the most striking features of the Middle Kingdom: it is manifest in its social problems, in its moral degradation and material misery [Fig. 4] and, above all, in its superstition. Vráz actually prophesies a monumental future for 'this colossus that can resuscitate', but only if China can be 're-born, freed from its reactionary and dishonest rulers'; only if it becomes 'enlightened, relieved from its delusions and the most childish superstitions. ${ }^{\prime 31}$

27 'When I stayed in China for the first time, in Shanghai, my friends tried to talk me out of visiting Beijing. This is what I was I told by the American ambassador: 'you will climb the mounds of the Tartar City and you will have to bargain, because only by bribing the guard will you be able to get to the top, and you will regret having come. You will see many roofs and imperial gardens, and countless roofs of temples. And all covered by the legends of centuries, embellished by your premonitions, made a fairy tale by your imagination, and it will remain forever unattainable for you. You will not be allowed to step under those roofs. The little we, the foreigners, are allowed to see in Beijing is not worth the travel and the expenses'.' Vráz 1904, p. 318.

28 The entire paragraph reads as follows: 'Starting already in the period of 1839-1842, in the so-called 'opium war', China has constantly been a target of raids and humiliation from the whites. The sons of the Middle Kingdom who consider themselves the Sun in the planetary system of the nations, looked with displeasure at the fact that the 'barbarians', instead of falling to their knees in front of the 'Sons of Heaven', were doing them wrong, invading China and, in fact, starting to take their share of it, as if it were a banquet table, at which any unwelcome guest can sit down as he pleases.' Vráz 1904, p. 6.

29 Cf., for example, the following comment: 'The exceedingly superstitious son of the reign of queues would consider it a bad omen [to praise the health of a host's children], since he believes in the power of the evil eye, in evil deities and envious phantasms that animate the air and dwell in the five Chinese elements.' Vráz 1904, p. 169. 


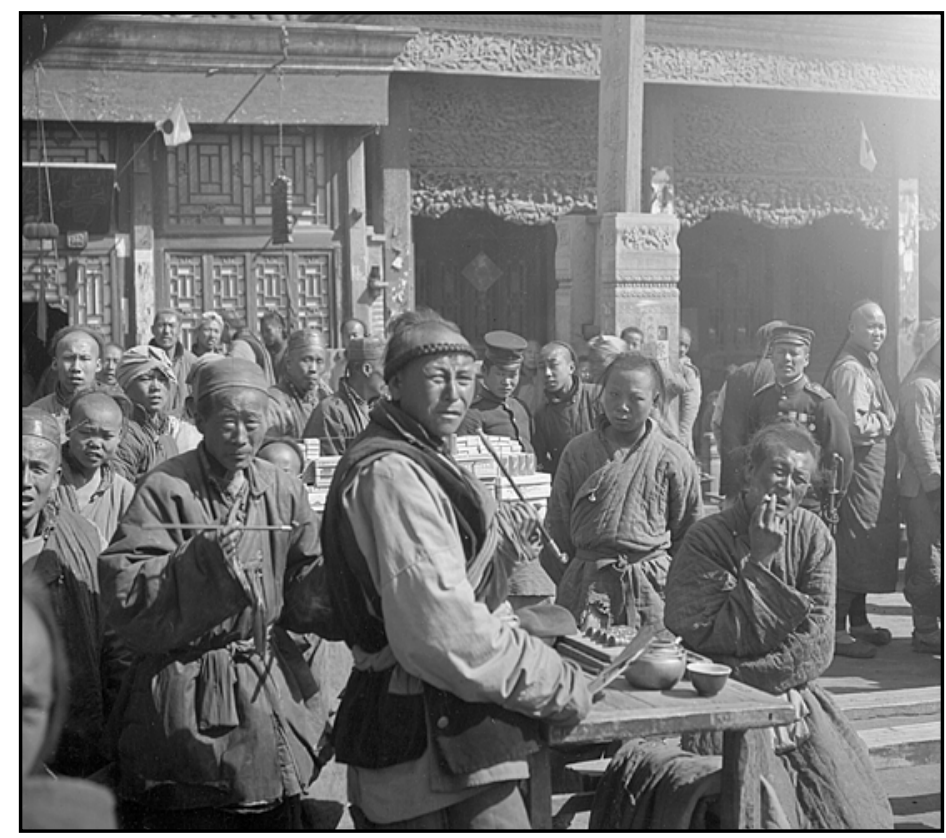

Fig. 3. A group of men around a fortune-teller. Vráz's own label reads as follows: 'He threw marbles balls, wooden boards; according to the result, he would tell fortune.' Náprstek Museum, Inv. no. As I 7151.

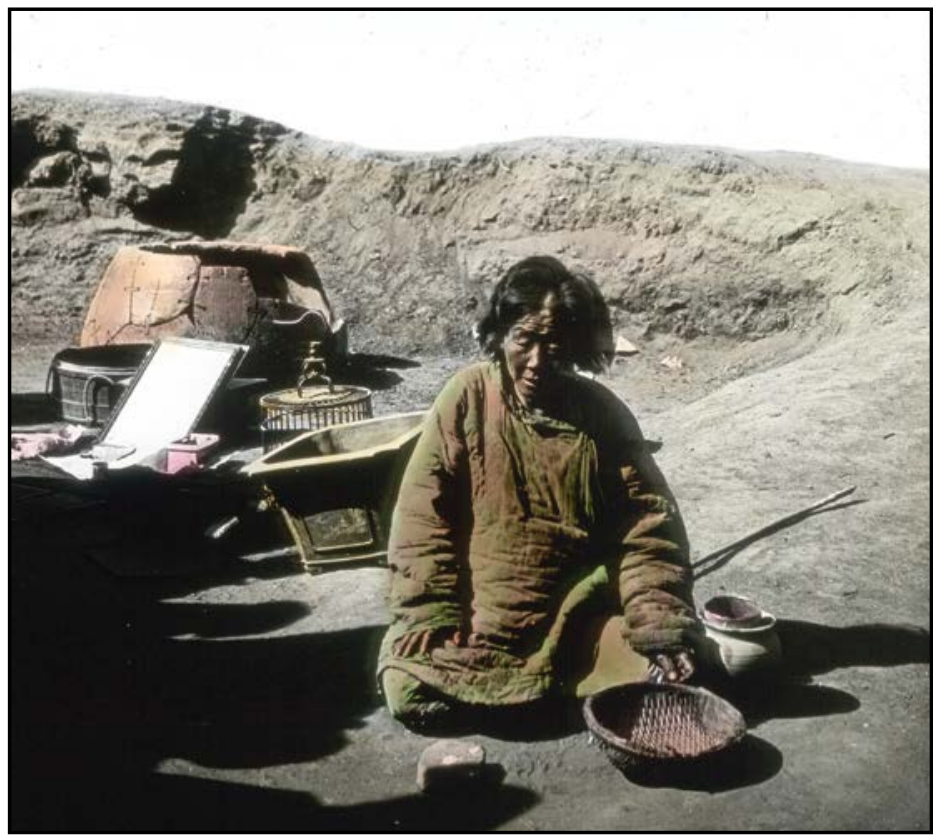

Fig. 4. A beggar on the side of the road. Vraz's own label reads as follows: 'When he receives nothing, he knocks his head against the brick.' Naprstek Museum, Inv. no. As II 4298. 
It is essential, however, to point out that Vráz does not forge the opposition between barbarism and civilization or culture as an antagonism between, on the one hand, China and, on the other, Western nations that presumably come to redeem and enlighten an excessively obscurantist, archaic, and traditionalistic society. He does not construct a Eurocentric (or Westcentric) antagonism between the darkness of the Chinese underdevelopment and the light of Western progress. In other words, the shadows he finds in China do not blind him to the perils of the darkness of the West, with all its progress and scientific advancement. In Beijing of 1901, barbarity reigns everywhere [Figs. 5, 7], and in any case can be ascribed only to the Chinese: it is omnipresent in the cruelty, the denigrating attitude and the feeling of superiority of the Western soldiers [Fig. 6]:

With utmost indignation must I condemn the way in which [...] almost without exception, European soldiers exhibit their gallantry, slapping, kicking, and pummelling all those who wear a queue, if these do not understand immediately the novelty or do not respond swiftly to the order; or if they dare, with a mere look, to challenge the brute who, back at home, would not look better or smarter than the miserable Chinese creature. ${ }^{32}$

Vráz does not identify one single culprit of the brutality in which he finds himself immersed. He knows all too well that the contemporary situation in China is extremely complex, full of contrasting tendencies. There are two approaches of the Western powers towards contemporary China, he explains. One is keen about conserving the power the reigning dynasty, the 'corrupt Manchu clique' (that comprises the Boxers, the Empress, and the court eunuchs, towards which the Chinese common people show indignation), and its motto is 'leave China to the Chinese'. The second approach, in contrast, has already issued a death sentence: 'Rotten China, country of yellow barbarians, has lost all its rights. Show no mercy to it, and do not feed in it those who murder defenceless women and children. What can be done about a people who, in its superstition and cruelty, can only be compared to the Dahomey? ${ }^{33}$ The world belongs to the enlightened whites!'34

32 Vráz 1904, p. 77.

33 The Kingdom of Dahomey was an African kingdom, defeated by the French in 1904. It was located in the area of modern Benin. The Dahomey people were known for their cruelty and human sacrifices. It is worth noting that Vráz, during his visits to West Africa, stayed with the Ashanti people, who also practiced slavery and human sacrifice. See Vráz 1983, pp. 68-77.

Vráz 1904, p. 1. 


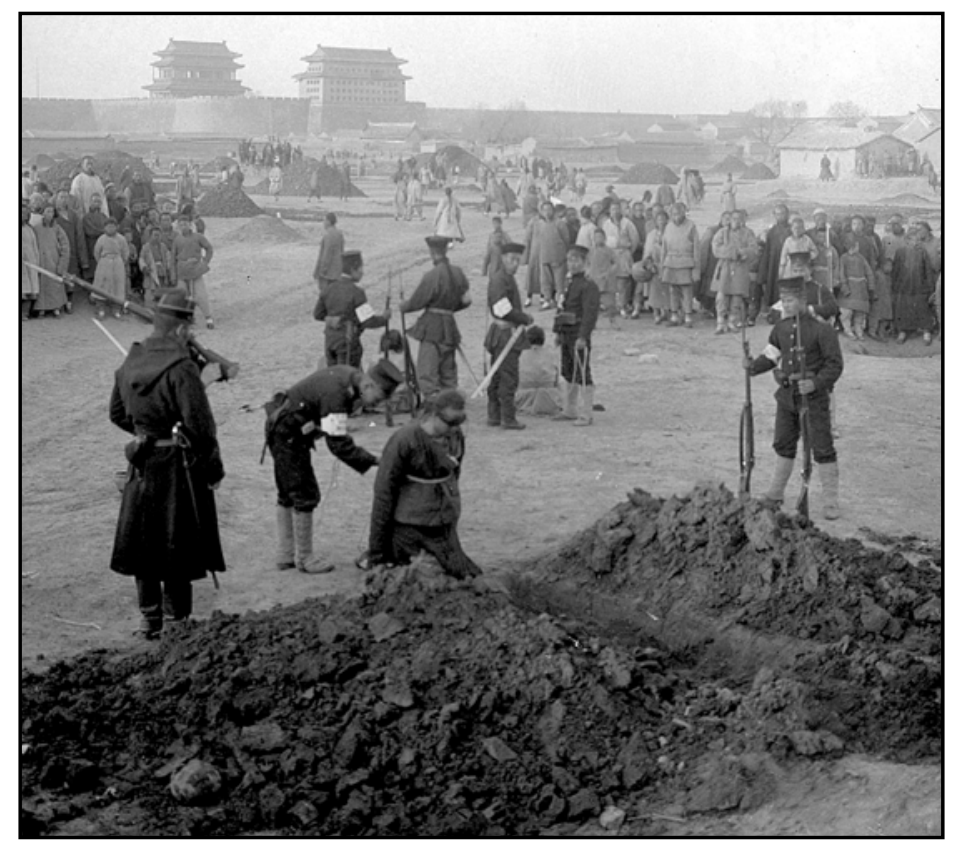

唄

Fig. 5. Vráz's own label reads as follows: 'The execution of Chinese Boxers by Austrian [?] soldiers; 3 of them already lying in the grave.' Náprstek Museum, Inv. no. As I 81 V.

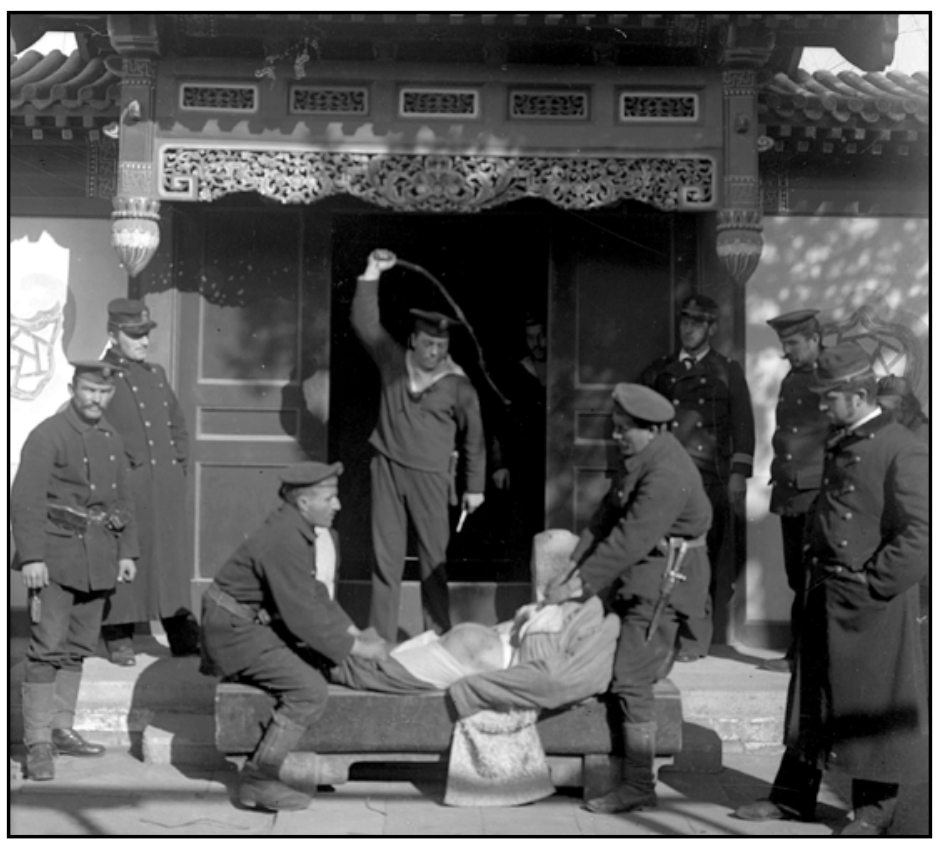

Fig. 6. Vráz's own label reads as follows:

'The Austrian garrison punishing a Chinese offender.' Náprstek Museum, Inv. no. As I 79 V. 


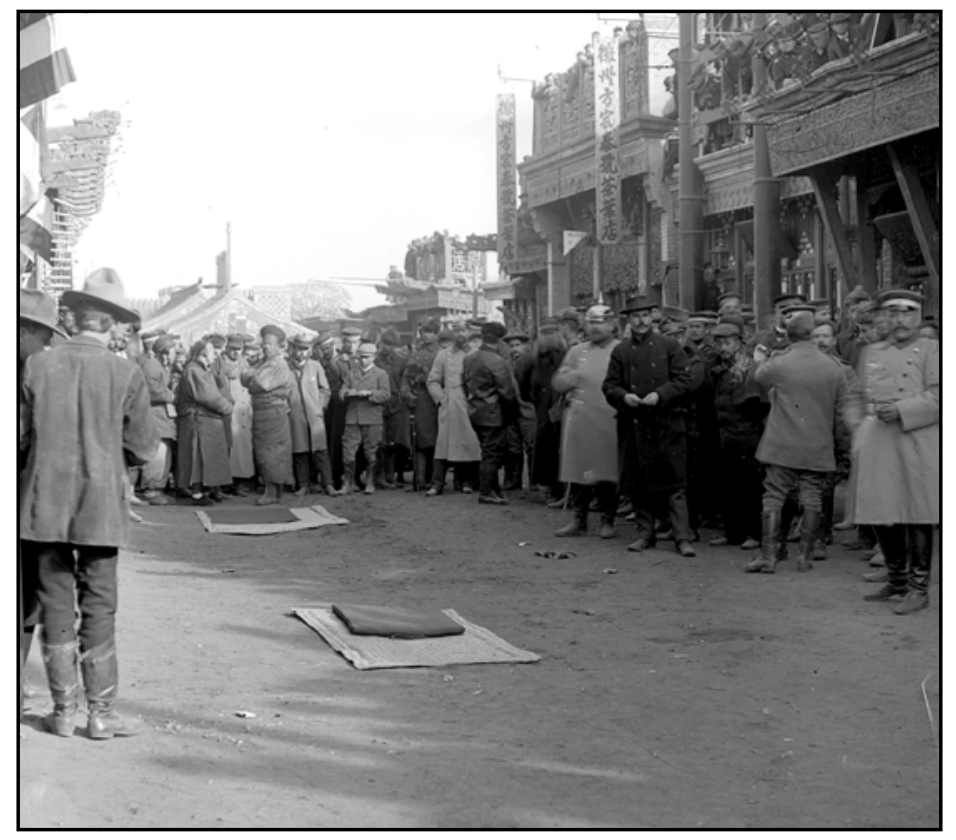

Fig. 7. Vráz's own label reads as follows: 'In my presence, two mandarins were executed, condemned of the Boxer crimes by white-man garrison.' Náprstek Museum, Inv. no. As I 41 V.

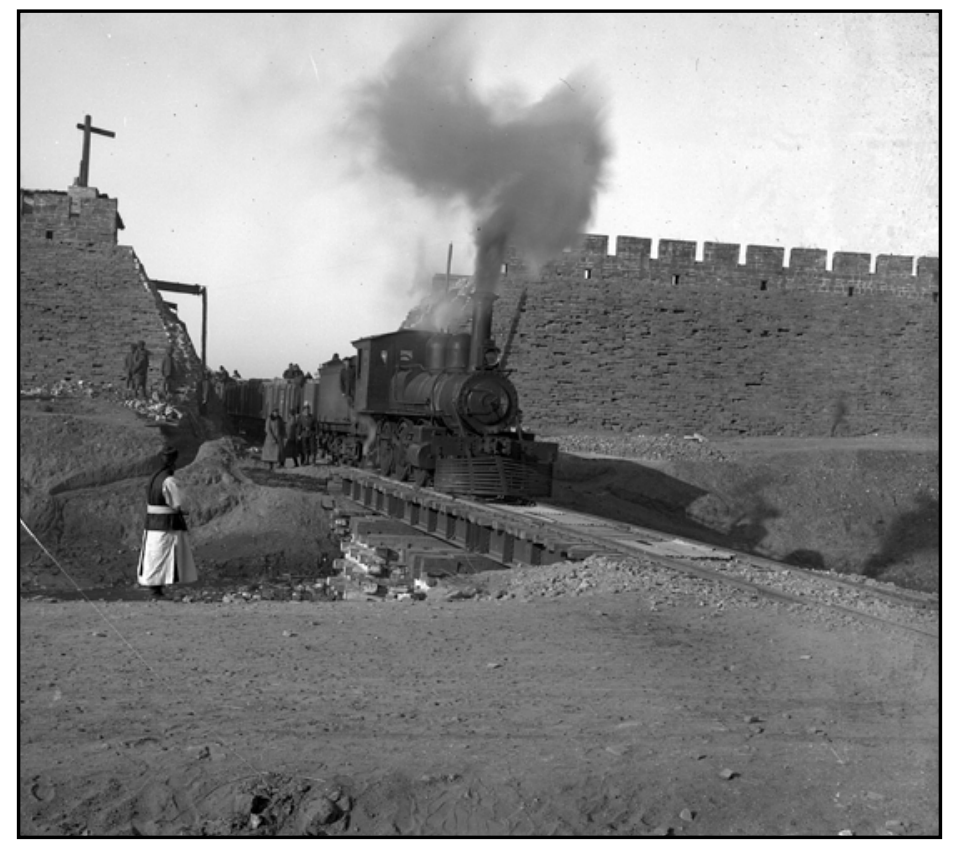

Fig. 8. Once Beijing was defeated, the train made its way into the city. Náprstek Museum, Inv. no. As I 1737 a. 


\section{Phantasms of Europe in China}

In this way, Vráz increasingly focuses his narrative on the abusing attitude of the 'whites' who pursue only their own commercial and political interests. In this context, he employs a specific Czech expression, 'cizota', as one of the central factors in explaining China's situation. It refers to being, first of all, 'foreign', 'other', or 'unknown', but cannot be limited to these meanings, because it also connotes a menacing and foreign alterity. In Vráz's text, it designates an almost alien body, introduced into China and destroying it from within. The most eloquent expression of this 'dis-encounter' is his description of the triumphal entrance of the train into the Forbidden City [Fig. 8]. The place once taboo and inaccessible but for a selected few, has been invaded by the train tracks (and Vráz seems to be particularly sensitive to these all-telling symbols of a new order). ${ }^{35}$

Vráz, in short, is extremely ironic about the 'culture' of the Western colonists, ${ }^{36}$ as he offers us the following image of evil and cruelty in the human soul, inherent to human nature in general:

What savageness there is in the depths of the human soul! What a sleeping atrocious beast, in some only dozing, in others resting with the slumber of enchanted princesses - it will, alas, awake, and once awakened, it is bloodthirsty and bestial. Who, for example, could suspect in these Cossacks, who are now playing in the streets of Beijing with Chinese children [...] those fierce men, thirsty for a fight, attacking and murdering in frantic intoxication? Who would identify those gallant courteous French and Italian smart dressers as culprits of the death of hundreds, even thousands, of Chinese girls and women who, sometimes for a mere joke by a soldier [...] pushed by the offence, jumped into a well in order to avoid shame and disgrace. Alas, how many girls and women were raped! How many brothers and husbands, defending their beloved ones, were beaten to death, since they were resisting the European civilization! ${ }^{37}$

He repeatedly points out that those who should presumably be the bearers and agents of 'civilization' are, in fact, the biggest predators. Under certain circumstances, all men behave like beasts, often under the disguise of 'cultural colonialism', which, in his view, goes hand in hand with aggression, brutality, and militarism:

At the end of the $19^{\text {th }}$ century, many Kulturträger ${ }^{38}$ were in a hurry to show that in all but courage they can be compared to the Huns [...] so many crimes were committed against humanity and the true education that the white race [...] uses to boast its superiority over others. It was precisely militarism, the spoiled child

35 Vráz 1904, p. 78.

36 Cf., for example, Vráz 1904, p. 115, where he refers to the 'loose morals of the soldiery' as a means of 'introducing culture to China.'

37 Vráz 1904, p. 108.

38 Vráz uses here the German expression, but in its Czech rendition - 'kulturtégr'; in German, it refers ironically to someone who transmits supposedly 'higher' cultural ideals, to the so-called 'upholders of civilization'. 
of certain circles, to disclose once more how much barbarism and vandalism due either to the legacy of blood or to the ill-advised upbringing - is still lingering in the white, Christian, enlightened race. Once again it was confirmed that the much-admired idol of its enlightened humanness is always (not only in the pagan times) powerless and feeble in confrontation with the sword. ${ }^{39}$

There is a very eloquent image of this cultural predatory colonialism (and of a failed 'cultural encounter'): once again in the Summer Palace [Figs. 9, 10], Vráz contemplates, in the wall niches, uncountable figures of idols. Unfortunately, they are all charred. The Italian guard, he explains, 'was in charge of patrolling part of the palace, and they were cooking their macarons too carelessly. The bursting fire almost engulfed the entire place of worship. ${ }^{40}$

It is worth noting that there is one important aspect to these scenes of destruction and war crimes. They are closely related to the national identity of their perpetrators. ${ }^{41}$ Vráz personally blames the plundering especially on the Germans: 'The Germans, even though they appeared rather late on the stage of the Chinese war - or maybe just because of it - showed, according to Tianjin authorities, enormous hunger, and went as flocks of locusts after what has been already plundered by others. [...] One of the reasons for their [plundering] expeditions was also to get their 'justified access' to the Chinese treasures.' Vráz consequently condemns particularly the German cruelty towards the civil population, which has already caused 'public outcry even among the German people themselves!'42 Here we are confronted, in all probability, with nationalist feelings common in contemporary Europe, especially since Vráz draws an interesting parallel between the Germans and the Russians. ${ }^{43}$ My impression is that he is not expressing a personal unfavourable view towards certain nationalities, but rather giving voice to enmities and the growing estrangement of the leading powers in Europe, which ultimately led to the outbreak of the First World War. Be it as it may, it is undeniable that national identity is an important category in Vráz's thinking and writing. In point of fact, one of the most important objectives on his way back to Europe (he left Beijing at

39 Vráz 1904, p. 97.

40 Vráz 1904, p. 361.

41 The construction of national identity in the travel literature is an immensely complex problem, and it is impossible for me to assess it here in a satisfactory manner. I therefore refer the readers to the collection of essays Escaping Kakania: Eastern European Travels in Colonial Southeast Asia (forthcoming, see note 7). All contributions in this volume ponder on the construction of national identity in Central Europe in the genre of travel narrative. See also Neumann 1998. For a theoretical discussion of the construction of national identity through the confrontation with the Other during the travel (albeit in a completely different geographical and chronological context), see Cox 2005, Introduction; and Perraudin and Zimmerer 2011, esp. the essay 'Time, Identity and Colonialism in German Travel Writing on Africa, 1848-1914', authored by Tracey Reimann-Dawe.

Vráz 1904, p. 105.

Theard this interesting comparison between the Russians and the Germans from the secretary of the local government in Tianjin. 'It is true, when speaking about the Russian soldiers, that they were behaving sometimes in an atrocious way: fighting like savage beasts, very heroically, but showing no compassion to the guilty and the innocent, be they old men, women, children. Kill and kill! And then they were victorious and lo! there is not a softer and heartier man than the Cossack. I heard less laments against them when peace was already reigning. The Germans, in contrast, even though they entered China after the fights were over and found quite an orderly situation, would still treat the local people, humiliated and filled with fear, with cruelty'.' Vráz 1904, p. 106. 
the end of April 1901, and his journey led him through Korea, Mongolia, and Siberia) has a considerable 'nationalistic' aspect to it: he wants to explore old Slavic literary testimonies, once seized by the Tartars, and currently presumably in the Empire's library in Mukden in Manchuria. Vráz exhibits here the spirit of Pan-Slavic unity, one of those political and national principles that shaped the destiny of Europe at the end of the $19^{\text {th }}$ and in the first decades of the $20^{\text {th }}$ century. ${ }^{44}$

He also mentions his own homeland, 'Austria'. The Empire sent, he says, 'only a small garrison. I did not hear anything shameful about it [...]. With great joy I can testify here that, with the exception of a small robbery [...], there was no other army behaving in such a just and humane manner. [...] I made the acquaintance with many Austrian officers, either Slav or German [...] all of them made a huge effort so that the reputation of the Austrian army in China would not meet with shame. ${ }^{45}$ Despite his pride in Austria [Fig. 12], he describes himself as 'an American citizen'46 and often emphasizes his Czech origin: a Chinese pharmacy in Beijing evokes in him 'our Old Prague' 47 , and his heart is filled with joy when he meets five Czech sailors in the Austrian garrison in the city. ${ }^{48}$ He then lists some Czechs with whom he strolled through the Empire's palaces and temples, amidst the 'sound of my beloved Czech mother tongue', ${ }^{49}$ to which he also refers to as the sweet mother tongue I listened to on the Prague theatre stages. ${ }^{\prime 50}$ Even the fairy-tale atmosphere of the Summer Palace [Fig. 10] brings to his mind a memory of his homeland:

[the sweet smell of the Summer Palace lake] reminded me of my dear friend, at that time still alive, the great Zeyer ${ }^{51}$ of blessed memory. I was full of sorrow that he who depicted so many times, with the sole power of his fiery imagination, the phantoms from the realms of oriental tales, did not undertake a journey here, a long but rewarding journey. He would have brought back countless treasures. ${ }^{52}$

This 'national' or 'nationalistic' aspect embodies a recurring motif that appears here and there, as the silver thread of the enchanted princess, when Vráz, for example, describes the beauty of the Summer Palace. He employs a very poetical language, appropriate for this fairy-tale atmosphere. He pictures, however, a scene of decadent beauty, of a long-lost splendour; he narrates the history of a decline, of a corrupt and self-indulgent empire, and this somehow, at least symbolically, runs parallel to the imagery

44 Vráz 1904, p. 392. Once in Manchuria, Vráz further inquired about this matter, but unfortunately was informed that his sources were incorrect. More importantly, he then reports (thus emphasizing, once more, the Pan Slavic idea) being told that 'if anything of that kind had been found there, of such importance and concern for Panslavism, it would have been undoubtedly transported to Petrograd.'

Vráz 1904, p. 273.

Vráz 1904, p. 274.

Vráz 1904, p. 184.

Julius Zeyer (1841-1901), Czech poet, prose writer, and playwright. In his works, he often combined foreign legends and mythologies, together with Czech national and historical themes and motifs.

Vráz 1904, p. 367. 


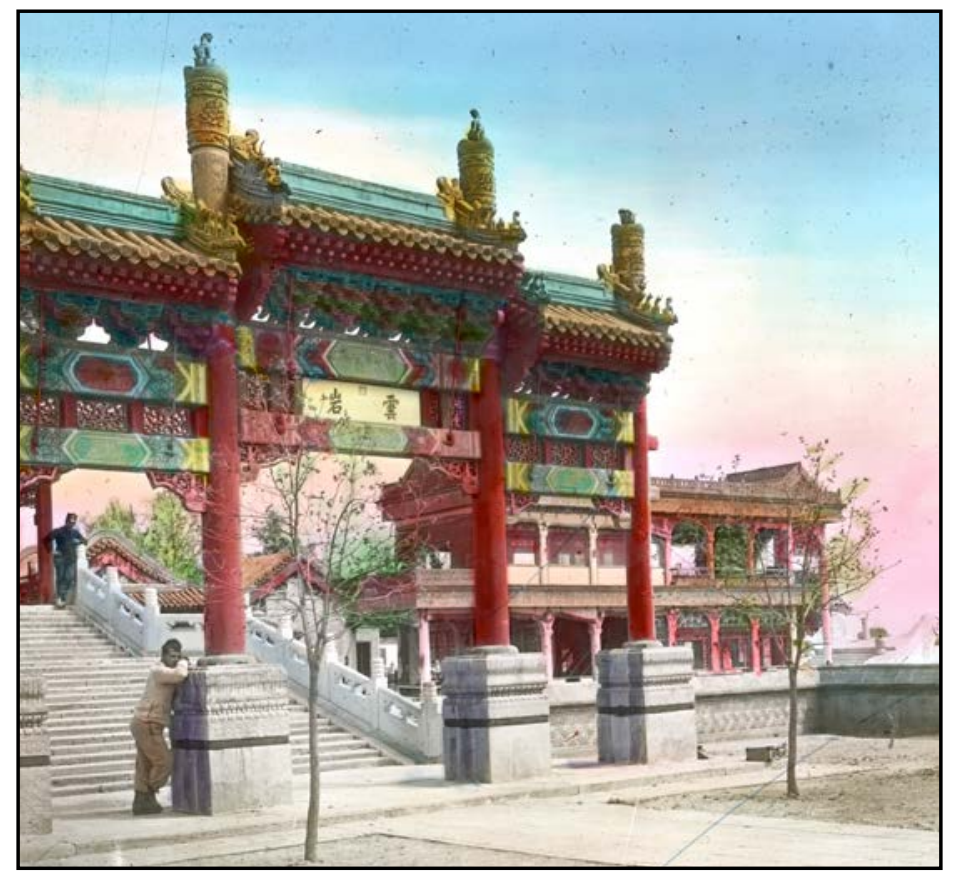

Fig. 9. The Summer Palace, with an Italian (?) soldier leaning against the column. Náprstek Museum, Inv. no. As II 1825.

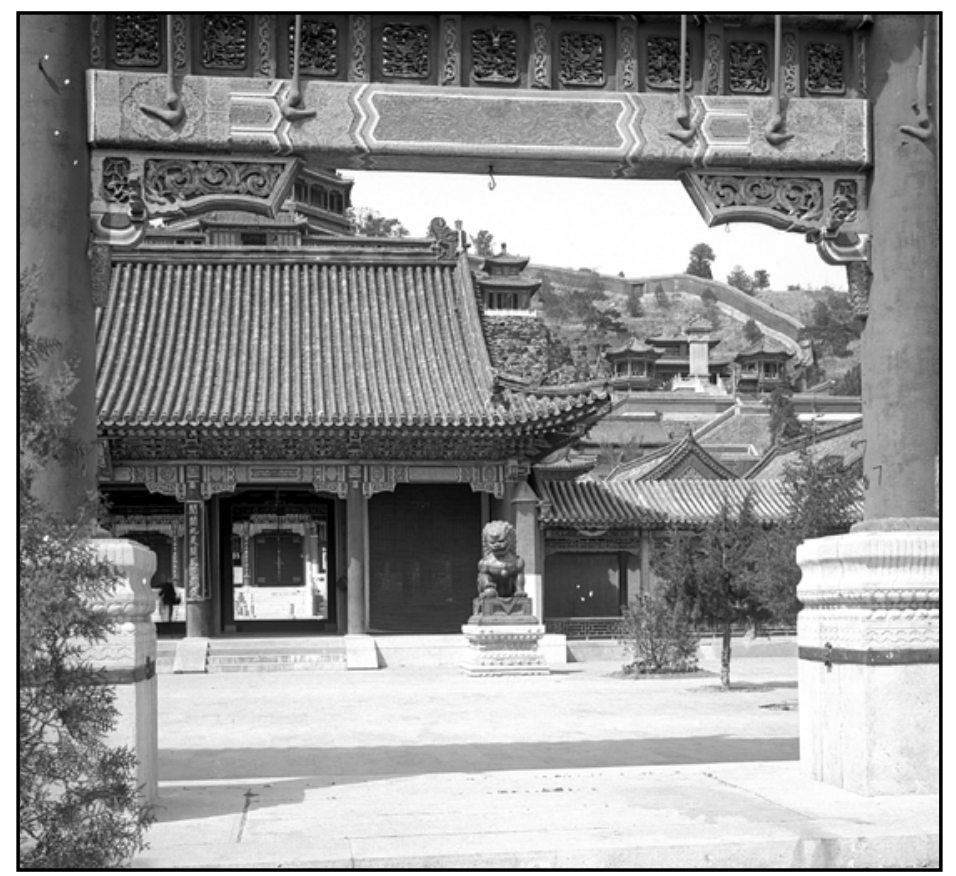

Fig. 10. The courtyards and pavilions of the Summer Palace. Náprstek Museum, Inv. no. As 7071. 


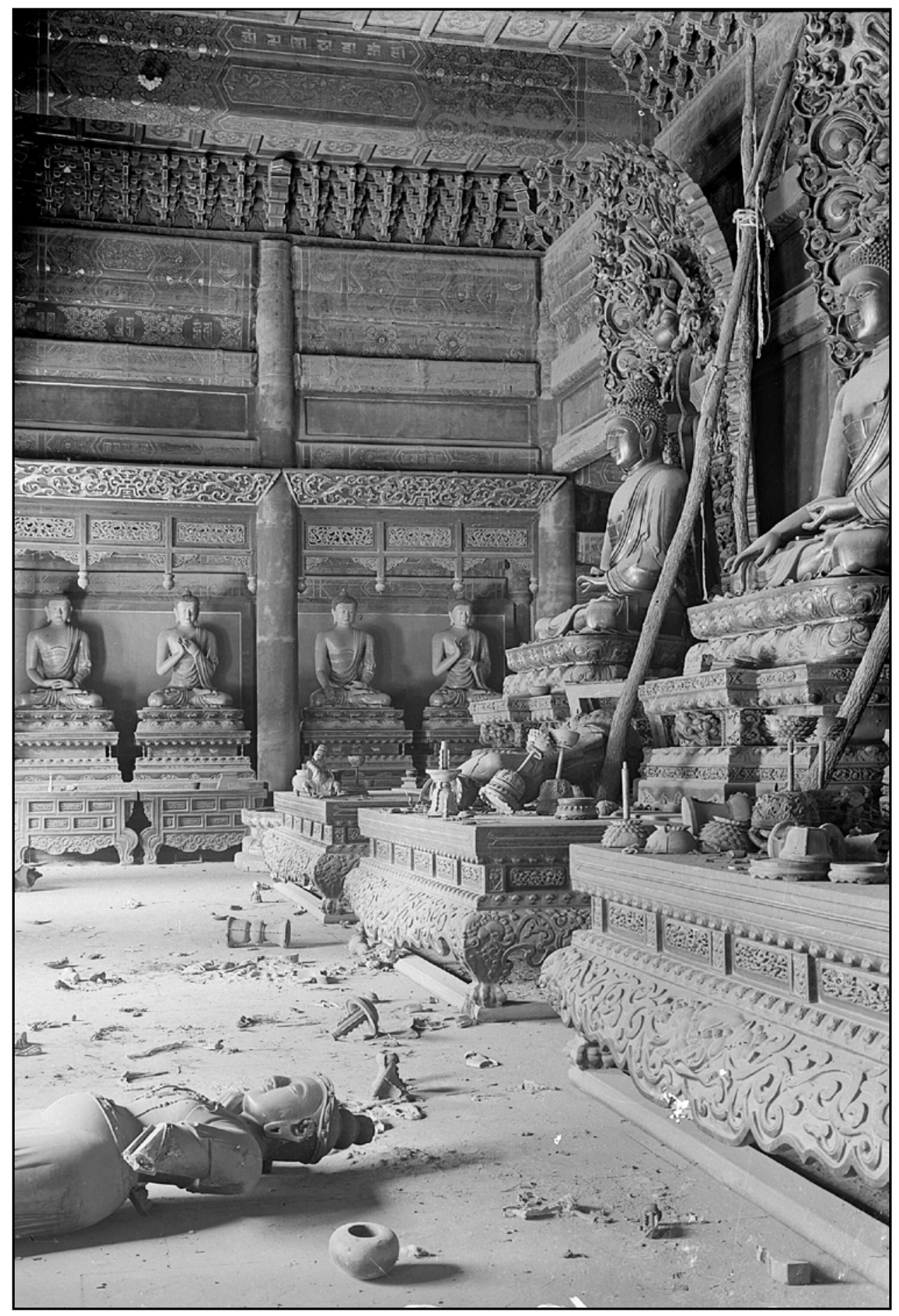

唄

Fig. 11. The Lama Temple in ruins.

Náprstek Museum, Inv. no. As I 7056. 
back in Europe, still immersed in the joy of the fin-de-siècle spirit, an inflated festivity that anticipates the coming disaster: 'We are passing by walls from where all the paintings have been stripped off by the bestia triumphans. From the past beauty, only rags, broken lampions and the coloured glasses of the partition-walls and windows remain.' It is the image of fugacity, of the transient majesty devoured by inexorable time and the sometimes radical transformations of history, ${ }^{53}$ an image replicated in one of the most telling and most complex passages in Vráz's text, the description of his navigation before reaching the Chinese coast. The ship on which he was travelling was called Progress (how ironic!), but, as he explains, he himself suggested to the captain it rather be re-named as 'Babylonia', because 'it would be difficult to assemble more international a party': Progress was built in England, passed into the possession of a Siberian company in Vladivostok, where it provided regular travel between Kamchatka, Sakhalin, and Vladivostok. At the time of Vráz's travel, she was rented out to the German government and thus carried, besides the Russian flag, the German post flag. Her captain and steersmen were Norwegian and the second engineer a Czech-German from Teplice. The ten-member crew was composed of Siberian and Cantonese Chinese; the cook was a Chinese from Shanghai, the heating mechanics all came from the 'lairs of the harbour of Amoye's pirates'. On the tween decks a Manchu, Korean, Japanese, two Hindus (probably servants of some captain in Tianjin), and Chinese from Shanghai and Zhifu. The company of the 'so called first class' was as diverse and multinational: 'a North American, a Portuguese mestizo from Macao, Danish, English, one Romanian, and one Hungarian Jew, both speaking half a dozen languages and both pursuing the Golden Idol of the Tianjin' ${ }^{\prime 54}$ - these cheerful terms are used by Vráz to describe this multinational and multifarious company on the ship, as an image of the placid co-existence of different nationalities on the ship of such a mordant name. Then, the atmosphere, almost without warning, changes abruptly: 'These seafarers on the Progress', he explains, 'with the sole exception of myself and a missionary doctor from America, were all driven and urged by one single gigantic force, the same that propels the wings of ravens when they detect the smell of a corpse. ${ }^{.55}$

This alarming last phrase is a foretaste, so to speak, to the plundering of the allied forces during the Boxer Rebellion; before anything else, it must be related, however, to a far more distressing picture provided by Vráz after referring to the account of Mr. Knobel, the Dutch ambassador who was shot in the leg during the Rebellion and who described to Vráz, very vividly, the tragic scenes of the defence of the foreign representatives in the Legation Quarter. Vráz then reflects upon the ambassador's narration:

Almost unconsciously, I compared [those] facts with, on the one hand, the enduring circumstances, and, on the other, with the phantasms that seem to prophesy the germination of new historical formations. In this gloomy reverie, I did not ponder, at first, over the steep curves of the questions that were making their way, like zigzagging lightings, through the muddy horizon of enigmas. I did not realize, at first, that my bestirred imagination, with its enlarged pupils, was searching eagerly in the far distance for a new yet unknown image to be

53 Vráz 1904, p. 360.

54 Vráz 1904, p. 71.

55 Vráz 1904, p. 71. 


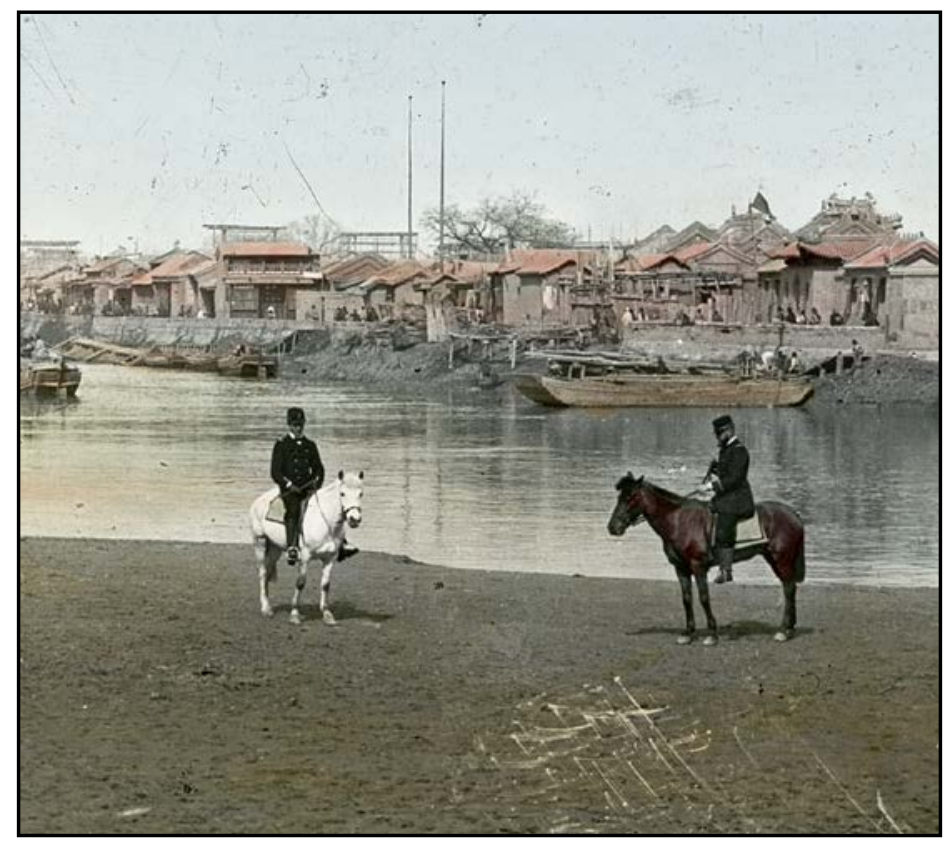

Fig. 12. Two Austrian army officers on horses. Náprstek Museum, Inv. no. As II 1765.

projected upon the retina by the close future. Then I started to shiver, when I became finally fully aware of the feeble images that, in response, were going through my ignited mind. I saw savage groups of Hindus, coming back home not as the welcomed liberators of the Chinese Christians and of the besieged Europeans, but rather as insurgents and as raging pursuers of all foreigners. And [I saw] troops of cultivated Europeans, until recently marching in mutual concord, but soon ignited by an irreconcilable hatred, competing against one another in the deplorable efforts of the murderers and devastators of a common homeland - Europe. In the end, in the distance, in the far misty distance on the horizon, I saw Asian hordes rolling, paying visit to the disunited, divided kingdoms and homelands of Western culture. ${ }^{56}$

In 1901 and in China, Vráz experienced this extraordinary premonition about the future of Europe. Little could he know that his vision was, at least in its first part, to become true in the cataclysm of the First World War. He himself rejects his own oracular and channelling skills ('I do not think I have a prophetic spirit'), but this singular apocalyptic image causes a huge impact on him (that is probably why he felt compelled to enclose it in such poetic and dramatic language, uncommon in the rest of his texts): 'I would never wish my vision of the Beijing mounds to ever come true' ${ }^{57}$ Unfortunately, his intuition foretold exactly the future of Europe. Paradoxically, China uncovers in Vráz 
the gift of prophecy, a gift that he as a positivist scientist could not accept, at least not consciously. ${ }^{58}$ In a sense, he had to travel to China just to be able to envision prophetically the imminent destiny of his homeland, the definitive extermination of the 'old Europe'. It is in China where he could see what in Europe only few could or dared to.

In my Beijing temporary dwelling, an old palace, Vráz explains, its previous owner managed to bury, just before the outbreak of the Boxer Rebellion, a 'treasure he was then able to recover once it was over. ${ }^{59}$ This is just an interlude in Vráz's report, but it is appropriate to close my own exploration of this author's narrative, which can be conceived as an unexpected treasure, if we are able to free it from its slightly obsolete language and focus on its marvellous and paradoxical apprehension of a country which in itself is a paradox, on his sharp analysis of the international state of affairs, and on his premonitory vision of the future of the world. Vráz's account of the Middle Kingdom can be directly related to his own homeland, Austria, not only because it is a story of lost splendour, full of nostalgia for a decadent empire on its way out, but mainly because it is a testimony to the confrontation between the so-called 'civilized world' or 'educated Europe' with the bestia triumphans of colonialism, militarism, and nationalism.

Vráz's report bears witness to a country amidst chaos; it represents the ultimate warning of a clairvoyant and wise man against the destruction in China which is but a mirroring image of the devastation that awaits Europe, in its own struggle between civilization and barbarism, between darkness and light. I hope to have shown that his travelogue defies any unambiguous and uncomplicated reading; it should not be contextualized, at least not without caution, within the ethnocentric travel writing of the end of the $19^{\text {th }}$ century, dependent on the colonialist and imperialist frame of mind and reference. Vráz's narrative does undoubtedly employ the typical colonialist oppositions (analysed in the ever-growing body of postcolonial scholarship), but he does not elaborate a discourse of antinomies of 'us versus they'. He instead apprehends them in an extremely paradoxical way, making the boundaries of 'barbarism' and 'civilization' shift constantly and blend into one other. His narrative is, in summary, a perfect diagnosis of his world. Perhaps it was his bitter condition of a globetrotter, lacking any deep roots,

58 Cf., once more, his harsh criticism of the Chinese superstition and divination practices, especially geomancy: 'Not even the primitives in Africa or New Guinea live in a bigger dread of evil deities than the Chinese! It is of no surprise that geomancy practitioners are extremely prosperous here. Even the biggest laggards and criminals try to become the biggest laggards and criminals try to become Taoist priests.' Vráz 1904, p. 299. Cf. also his ironical quotation marks in the following statement: 'These geomancy practitioners are called, in Chinese, 'Sien Sang'. These prophets and magicians pertain, for the most, to the class of the literati, that is to Chinese scholars, followers of the 'science'.' Vráz 1904, p. 299. Cf., ultimately, the following: 'Apart from the above mentioned religions [...], a thousand years of superstitions have chained the mind of the people. We find in China worshippers of animals, trees, stones; we find belief in the power of evil men to transform into animals, belief in the effects of certain numbers and dreams, in the influence of the air and the earth, in wind and water geomancy [fengshui]. Certain classes of Chinese people, such as for example carpenters, bricklayers, and miners, are often accused of practicing witchcraft. It is of no surprise, then, that a European, especially if he conducts research or takes photographs, be he a tourist, an engineer or a geologist, often raises the people's anger, and becomes an involuntary originator of the so-called hatred of the foreigners, imputed to national (!) and to religious (!) causes. The most foolish of the Chinese superstitions, feng-shui, is precisely the one that causes the most disputes, even explosions of passion against the foreigners resident in China and against the missionaries.' Vráz 1904, p. 303.

Vráz 1904, p. 275. 
the one thing that allowed him to see the perils of the 'civilized' world, thus overcoming his own positivist, rationalistic frame of mind and the ethnocentrism of his fellow Westerners: truly a voyager who, precisely because of his many travels, 'rid himself of many prejudices'.

\section{Acknowledgements}

All photographs come from the collection of Náprstek Museum of Asian, African and American cultures, Prague (Czech Republic). They were taken in 1901 in Beijing (with the exception of Vráz's portraits), and they provide an exceptional visual complement to Vráz's narrative. An extensive part of this collection can be accessed at the virtual archive of National Museum (http://vademecum.nm.cz/nm/).

\section{Literature:}

Berty, V. (2001). Littérature et voyage: Un essai de typologie narrative des récits de voyage français au XIX ${ }^{e}$ siècle. Paris.

Behdad, A. (1994). Belated Travelers: Orientalism in the Age of Colonial Dissolution. Durham.

Clark, S. and Smethurst, P., eds (2008). Asian Crossings: Travel Writing on China, Japan and Southeast Asia. Hong Kong.

Clifford, N. R. (2001). 'A Truthful Impression of the Country': British and American Travel Writing in China, 1880-1949. Ann Arbor.

Coltman, Robert (1901). The Yellow Crime. Beleaguered in Pekin. The Boxer's War against the Foreigner. Philadelphia.

Cox, J. D. (2005). Traveling South: Travel Narratives and the Construction of American Identity. Athens.

China. The Land and its People. Early Photographs by John Thomson (1979). Hong Kong.

Dawson, R. (1967). The Chinese Chameleon. An Analysis of European Conceptions of Chinese Civilisation. New York.

Ewertowski, T. (2020). Images of China in Polish and Serbian Travel Writings (1720-1949). Leiden.

Fairbank, J. K. and Goldman, M. (2006). China. A New History, $2^{\text {nd }}$ ed. Cambridge, Mass.

French, P. (2009). Through the Looking Glass. China's Foreign Journalists from Opium Wars to Mao. Hong Kong.

Fritzsche, S. C. (1995). Narrating China: Western Travelers in the Middle Kingdom after the 
Opium War. PhD thesis, University of Chicago, Chicago.

Gu, Y. (2013). What's in a Name? Photography and the Reinvention of Visual Truth in China, 1840-1911. The Art Bulletin, 95(1), pp. 120-138.

Gützlaff, K. F. (1838). China opened; or, a display of the topography, history, customs, manners, arts, manufactures, commerce, literature, religion, jurisprudence, etc. of the Chinese Empire, vol. II. London.

Gützlaff, K. F. (1840). Journal of Three Voyages Along the Coast of China, in 1831, 1832, $\mathcal{E}$ 1833: With Notices of Siam, Corea, and the Loo-Choo Islands. London.

Hall, S. (1997). The Work of Representation. Introduction. In: Representation: Cultural Representations and Signifying Practices. Thousand Oaks, Ca., pp. 1-11.

Heroldová, H. and Todorovová, J. (2018). A Family Portrait: Enrique Stanko Vráz and the Qing Aristocracy During the Boxer Rebellion. Annals of the Náprstek Museum, 39(1), pp. 51-74.

Kerr, D., and Kuehn, J., eds (2007). A Century of Travels in China. Critical Essays on Travel Writing from the 1840s to the 1940s. Hong Kong.

Lucas, Ch. J. (1990). James Ricalton's Photographs of China during the Boxer Rebellion. His illustrated Travelogue of 1900. Lewiston.

Martínek, J. and Martínek, M. (1998). Kdo byl kdo - naši cestovatelé a geografové. Praha.

Neumann, I. B. (1998). Uses of the Other: 'The East' in European Identity Formation. Minneapolis.

L'oeil du Consul. Auguste François en Chine (1896-1904) (1989). Présenté par Dominique Liabeuf et Jorge Svartzman. Textes D 'Auguste François rassemblés par Pierre Seydoux. Chêne.

Old Photographs of Chinese Cities. Hong Kong, Macau, Canton, Amoy, Shanghai and Peking, 1865-1912 (1995). An exhibition held at the Mandarin Oriental Hong Kong in January 1995. Hong Kong.

Olša, J., Jr. (2011). Seven Czech Travellers in Korea: how they explored, viewed and described the country before World War II. In: Kang Hong-bin and J. Olša, Jr., eds, Soul roku 1901 objektivem E. St. Vráze a jak viděli Koreu další čeští cestovatelé - 1901 Photographs of Seoul by Enrique Stanko Vráz and Other Early Czech Traveller's Views of Korea. Soul, pp. 144-221.

Perraudin, M. and Zimmerer, J., eds (2011). German Colonialism and National Identity. London. 
Photographs of Imperial China. 1850-1912 (1978). Foreword by Harrison Salisbury with texts by Clark Worswick and Jonathan Spence. New York.

Pratt, M. L. (1992). Imperial Eyes: Travel Writing and Transculturation. London.

Qing, A. (2014). Imperial Nostalgia: Spanish Travel Writing in China (1870-1910). Arizona Journal of Hispanic Cultural Studies, 18, pp. 221-233.

Smith, A. H. (1894). Chinese Characteristics. New York.

Smith, A. H. (1901). China in Convulsion. New York.

Spurr, D. (1993). The Rhetoric of Empire: Colonial Discourse in Journalism, Travel Writing and Imperial Administration. Durham.

Stiborová, J. (1985). Review of: Enrique Stanko Vráz. Napřič rovníkovou Amerikou (připravila a doslov napsala Olga Kandertová, Panorama, Praha 1984). Český Lid, 72(2), p. 114.

Thiriez, R. (1998). Barbarian Lens: Western Photographers of the Qianlong Emperor's European Palaces. London.

Thompson, C., ed. (2016). The Routledge Companion to Travel Writing. London.

Thurin, S. S. (1999). Victorian Travelers and the Opening of China, 1842-1907. Athens.

Todorovová, J. (2016). Public Presentation of Non-European Cultures at the Turn of the 19th and 20th Centuries. Part 2: From Worlds Afar - The Lecture Activity of Enrique Stanko Vráz. Annals of the Náprstek Museum, 37(2), pp. 3-16.

Todorovová, J. (2016b). Public Presentation of Non-European Cultures at the Turn of the $19^{\text {th }}$ and $20^{\text {th }}$ Centuries. Part 1: An Analysis of the Collection of Vráz's Glass Slides in the Photographic Collections of the Náprstek Museum, Annals of the Náprstek Museum, 37(1), pp. 3-16.

Todorovová, J. (2006). Enrique Stanko Vráz. Záhadný cestovatel fotograf. Praha.

Todorovová, J. (2002). Enrique Stanko Vráz - cestovatel a fotograf, Český lid, 89(2), pp. 160-172.

Todorovová, J. and Klápštová, K. (2003). Indiáni Hopi ve fotografiích E. St. Vráze, Český lid, 90(4), pp. 345-357.

Todorovová, J., and Secká, M. (2004). Prezentace fotografických materiálů E. St. Vráze z přelomu 19. a 20. století ze sbírek Náprstkova muzea. Sborník z 12. odborné konference Současné trendy ve zpřistupňování fondů, Olomouc 18.-19.11. 2003. Brno, pp. 57-59. 
Todorovová, J. (2008). Děti celého světa na fotografiích cestovatele Vráze. In: Od početí ke školní brašně. Sborník z odborného semináře konaného 29.-30. května 2008 ve Východočeském muzeu v Pardubicích, Pardubice, pp. 95-101.

Todorovová, J. and Kandert, J. (2010). Sojourn of Enrique Stanko Vráz on the Gold Coast. Annals of the Náprstek Museum, 31, pp. 37-54.

Todorovová, J. (2011). Enrique Stanko Vráz: a Mysterious Man and His Photographs. In: Kang Hong-bin and J. Olša, Jr., eds, Soul roku 1901 objektivem E. St. Vráze a jak viděli Koreu další čeští cestovatelé - 1901 Photographs of Seoul by Enrique Stanko Vráz and Other Early Czech Traveller's Views of Korea, Seoul: Seoul Museum of History, pp. 12-30.

Todorovová, J. (2005). Obrazový doprovod českých cestopisů z přelomu 19. a 20. století. In: Problematika historických a vzácných knižních fondi̊ Čech, Moravy a Slezska: lidé okolo knih. (Autor - tvưrce - recipient). Sborník z 13. odborné konference Olomouc, 23. - 24. listopadu 2004. Brno, pp. 283-291.

Vráz, E. S. (1900). Např́ic rovnikovou Amerikou. Cestopisné črty. In: Cesty světem, vol. 1. Praha.

Vráz, E. S. (1901). V Siamu, zemi bilého slona. Cestopisné črty. In: Cesty světem, vol. 2. Praha.

Vráz, E. S. (1904). Čína. Cestopisné črty. In: Cesty světem, vol. 3. Praha.

Vráz, E. S. (1984). Napříč rovníkovou Amerikou. Praha. [An abridged edition of Vráz's account of his travel to Latin America].

Vráz, E. S. (1983). V dálavách světů. Výbor z cestopisů, uspořádala a k vydání připravila Ola Svejkovská. Toronto. [A selection of Vráz's travelogues].

Vráz, E. S. (1940). Bílý d'ábel v Pekingu. Toulky a dobrodružství v Číně. Praha. [A selection of Vráz's texts on China].

Vrázová, V. (1937). Život a cesty E. St. Vráze. Praha.

Weber, A. (2006). Le genre romanesque du récit de voyage scientifique au xix ${ }^{\mathrm{e}}$ siècle. Sociétés E Représentations, 1(1), pp. 59-77.

Wells Williams, S. (1848). The Middle Kingdom. A Survey of the Geography, Government, Education, Social Life, Arts, Religion, $\mathcal{E}$ of the Chinese Empire and Its Inhabitants. New York - London.

Wetzel, A. (1992). Partir sans partir: le récit de voyage littéraire au XIXe siècle. Toronto.

Wright. D. (2009). Review of: Thomson's China. Travels and Adventures of a NineteenthCentury Photographer, Journal of the Royal Asiatic Society, 6(1), pp. 143-145. 